\title{
Effect of soft drink towards heat cured acrylic resin denture base surface roughness
}

\author{
Pocut Aya Sofya*, Liana Rahmayani*, Rico Riski Candra Purnama* \\ *Department of Prosthodontic Faculty of Dentistry Universitas Syiah Kuala
}

\begin{abstract}
Introduction: The absorption of fluid in the heat cured acrylic resin is able to cause the increase in surface roughness. Absorption of acidic fluid such as soft drinks can cause even higher increase of surface roughness. The objective of this study was to determined the effect of soft drinks towards heat cured acrylic resin denture base surface roughness. Methods: Specimens of this study were 32 pieces of specimen with the size of $12 \times 12 \times 3 \mathrm{~mm}$. Sixteen pieces of specimens were kept in aquadest as a control group and 16 pieces of specimens were immersed in the soft drinks as the treatment group. Initial surface roughness was measured using surface roughness tester. The specimens were then immersed in both immersion media for 2 days. After immersion, the surface roughness of specimens were measured again. Results: Data obtained on the roughness measurements were analyzed using paired $t$ test with the results of the analysis showed a significant difference $(p<0.05)$. Conclusion: It was concluded that there was increased in heat cured acrylic resin denture base surface roughness after immersed in soft drinks solvent.
\end{abstract}

Keywords: Surface roughness, Heat cured acrylic resin, Soft drink

P-ISSN 1979-0201, e-ISSN 2549-6212 Available from:http://jurnal.unpad.ac.id/pjd/index

DOI:http://dx.doi.org/10.24198/pjd.vol29no1.12614

Submission: Feb 2017 Publishing: March 2017

\section{INTRODUCTION}

Acrylic resin is a material that has been used extensively in denistry, especially as denture base material. ${ }^{1}$ Acrylic resins can be divided into 3 types based on the activation of its polymer bonds, which are cold cured, light cured, and heat cured acrylic resins. ${ }^{2}$ Most widely used material for denture base is acrylic resin polymethyl methacrylate with the activation type of heat cured, because the heat cured acrylic resin has several advantages such as non-toxic, not irritating, not soluble in oral fluids, good aesthetical aspect, easily manipulated, easily repaired and slightly changed in its dimensional aspect, but the shortfalls of heat cured acrylic resin are the weakness in its resistance and its high permeability. ${ }^{3,4}$

One of the heat cured acrylic resin properties is its high permeability, that is easily absorb water. This fluid absorption process occurs slowly over periods of time, by the mechanism of absorption through water molecules diffusion in accordance to the law of diffusion. ${ }^{2}$ Diffusion is the net movement of substances through the 
gaps. Water molecules penetrate into the acrylic resin and fill gaps between the polymer chains, which led to the dissolution of the acrylic polymer chains, and increases the level of porosity. This is why the acrylic resin has lower hardness compared to metal, and make it easier to get scratched and having abrasion. Acidic content that contacted the resin accelerates the deterioration of chemical structures on the resin surface. This chemical destruction leads to a decrease in the level of surface roughness on the acrylic resin resulting in cracks and material resistance decrease. Micro cracks produced by direct contact with acidic fluids in a certain concentration and intensity level. ${ }^{5,6}$

Surface roughness is a condition where a surface condition of one object is wavy and irregular. ${ }^{7}$ The condition of the surface of heat cured acrylic resin denture base material inside the oral cavity will affect plaque buildup that will increase the amount of Candida albicans colony that can cause denture stomatitis. ${ }^{4,7}$ Acid is corrosive on all materials. According to the theory of "corrosive wear," there are combination of degradation, those are chemical degradation and matrix degradation in the form of resin matrix dissolution. ${ }^{8}$ Some factors that may affect the level of degradation of the acrylic resin polymer such as chemical bond in the polymer structure, the acidity, the composition of the copolymer and water uptake capability. ${ }^{8,9}$ The absorption of acidic beverages will react chemically with acrylic resin and fill in the pores of acrylic resin. Acrylic resins may be affected by acetic acid, in the form of concentrations increase or high $\mathrm{pH}$ that will weaken the bonding of acrylic resin polymers. ${ }^{2}$ The acidic state of the oral cavity can be caused by the consumption of acidic beverages. One of the acidic beverages is a soft drink that contains various kinds of acids such as citric acid, phosphoric acid, tartaric acid, and maleic acid. ${ }^{10,11}$

Soft drink is currently becoming the trend of modern society, and the consumption of this beverage continues to increase. It is shown from the sale of soft drinks that has been increased by more than $56 \%$ in the last 10 years and is now expected to increase $2-3 \%$ per year. ${ }^{12}$ In developed countries, this case had happened for long time, with the average of consumption at 12 cans per person per week in $1997 .{ }^{13}$ Based on the research done by Dewi ${ }^{14}$, soft drinks (carbonated beverages) were able to increase the roughness of acrylic resin surface. The habit of acidic beverages consumption will damage the acrylic resin denture. ${ }^{15}$

The objective of this study was to determined the effect of soft drinks consumption towards the surface roughness of heat cured acrylic resin denture base, due to inadequate data about such topic.

\section{METHODS}

The methods used was laboratory experimental research. Research deseign used was Control Group Design. This research was conducted at the Laboratory of the Polytechnic USU Medan and Pharmaceutical Microbiology Laboratory USU on July 2016. The specimen of heat cured acrylic resin shaped plate with the size of $12 \times 12 \times 3 \mathrm{~mm}, 12 \mathrm{~mm}$ of length, $12 \mathrm{~mm}$ of width, and $3 \mathrm{~mm}$ of thickness. Specimens that were used as a research sample had criteria such as follows, flat surface, not pored and smooth. The number of specimens used were 32 specimens with distribution of 2 groups consisted of 16 specimens, one group immersed in a solution of soft drinks, and the other group was the control group.

Tools and materials used were as follows: wax knife, spirit lamp, plaster knife, lecron carver wax, sonde, cuvette, porcelain pot, spatula and bowl, scales, plastic vials, wrench no.10, pressing tool, vibrator, stove, pots, micromotor, and $\mathrm{pH}$ meter; with measuring tools: surface roughness tester, base plate wax, Meliodent ${ }^{\oplus}$ heat cured acrylic resin, material separation CMS (Could Mold Seal), dental plaster cast, vaseline, plastic cellophane, sand paper no. $800,1200,2000$, and pumice; also used materials such as follows: soft drinks, aquadest, gloves, and masks.

The specimens were divided into 2 groups: group 1 and group 2. Group 1 was the control group that were soaked in aquadest, whilst the second group was the treatment group that were soaked in soft drink solution. Before the immersion was done, heat cured acrylic resin specimens were soaked in aquadest first for 24 hours at room temperature in order to reduce the residual monomers. ${ }^{16}$ Before immersed in a soft drink solution, the solution was first measured the 
acidity degree $(\mathrm{pH})$. The $\mathrm{pH}$ measurements were done with $\mathrm{pH}$ meters by dipping the electrodes into the aquadest to obtain a neutral $\mathrm{pH}$ first. After a neutral $\mathrm{pH}(\mathrm{pH} \mathrm{7)}$ was obtained, then $\mathrm{pH}$ meter electrodes was dipped into soft drink solution to got the $\mathrm{pH}$ value. The measurements were done daily and recorded. ${ }^{17}$

Each specimen was put in a plastic vial contained a aquadest and soft drinks solution, with each amounted as much as $20 \mathrm{ml}$, and stored in an incubator at the temperature of $5^{\circ} \mathrm{C}$ (for the treatment group). ${ }^{18}$ All specimens were immersed for 2 days to simulated the average person soft drink daily consumption habits for 20 minutes in 5 months period of time ( 20 minutes 150 days $=$ 3000 minutes $=50$ hours $=2.08$ days $)$. The immersion media was replaced daily. After immersion, the specimens were rinsed with aquadest and dried.

All specimens were measured using Surface Roughness Tester to determine the roughness values that obtained with accuracy of $0.01 \mu \mathrm{m}$ to $1 \mathrm{~mm}$. Profilometer radius stylus was $5 \mu \mathrm{m}$ with a scan length of $2.5 \mathrm{~mm}$. The measurement were performed before and after immersion in a aquadest and soft drinks solution, repeated three times and then counted and recorded the average results. At first, the specimen was placed on a horizontal plane, then the stylus was put from the tip of the specimens that have been marked, and the stylus will move along the surface of the specimen with the speed of $0.5 \mathrm{~mm} / \mathrm{sec}$. The roughness measurement were done at 3 point of measurements. The measurement results will be displayed on the screen of the tool. ${ }^{9}$

\section{RESULTS}

This research was conducted at the Laboratory of Mechanical Engineering State Polytechnic of Medan in July 2016. The specimen used in this study was Meliodent ${ }^{\circledR}$ polymethyl methacrylate acrylic resin that immersed in soft drinks solution under immersion time of 2 days. Then obtained the average value of surface roughness of heat cured acrylic resin before and after immersion in aquadest (control group) and soft drinks (the treatment group). The surface roughness of heat cured acrylic resin was measured using a surface roughness tester. Differences in surface roughness value before and after soaked in distilled water and soft drinks solution were shown in Table 1. The data then analyzed by using paired t-test.

Table 1. showed the average value of surface roughness of acrylic resin heat cured before and after immersed in aquadest was $0.103 \mu \mathrm{m}$ and $0.101 \mu \mathrm{m}$. The results of analysis using paired $t$-test showed no significant difference $(p<0.05)$ between before and after immersion in aquadest. The average value of surface roughness of heat cured acrylic resin before and after immersion in soft drinks solution was $0.077 \mu \mathrm{m}$ and $0.097 \mu \mathrm{m}$. The results of analysis using paired t-test however, showed significant difference $(\mathrm{p}<0.05)$ between before and after immersion in soft drinks solution.

Table 1. Statistical data analysis of surface roughness of heat cured acrylic resin before and after immersion in aquadest and soft drinks solution

\begin{tabular}{|c|c|c|c|c|}
\hline \multirow[t]{2}{*}{ Treatment } & \multirow{2}{*}{$\begin{array}{l}\text { Number of Specimens } \\
\text { (n) }\end{array}$} & \multicolumn{2}{|c|}{$\begin{array}{l}\text { Surface Roughness Value }(\mu \mathrm{m}) \\
\qquad(\mathrm{x} \pm \mathrm{sd})\end{array}$} & \multirow[t]{2}{*}{$\mathrm{p}$} \\
\hline & & Before & After & \\
\hline Aquadest & 16 & $0.103 \pm 0.049$ & $0.101 \pm 0.037$ & $0.859^{*}$ \\
\hline Soft Drink & 16 & $0.077 \pm 0.021$ & $0.097 \pm 0.029$ & $0.032^{*}$ \\
\hline
\end{tabular}

Table 2. Difference of average comparison of surface roughness value changes between the control group and the treatment group

\begin{tabular}{ccc}
\hline Treatment & Number of Specimens $(\mathrm{n})$ & $\begin{array}{c}\text { Surface Roughness Value Changes }(\boldsymbol{\mu m}) \\
(\mathbf{x} \pm \mathrm{sd})\end{array}$ \\
\hline Aquadest & 16 & $0.002 \pm 0.043$ \\
Soft Drink & 16 & $0.020 \pm 0.034$ \\
\hline
\end{tabular}


Table 2. showed the increase in the value of surface roughness before and after immersion in soft drinks solution was higher than the value of surface roughness after immersion in aquadest.

\section{DISCUSSION}

The objective of this study was to observed the change in the surface roughness of heat cured acrylic resins after immersed in soft drink solution. In this study found an increase in the surface roughness after the immersion. The average value of surface roughness of heat cured acrylic resin before and after immersion in soft drinks solution was $0.077 \mu \mathrm{m}$ and $0.097 \mu \mathrm{m}$ (Table 1 ). The roughness is the characteristic of a corrugated or irregular body surface. ${ }^{4}$ However, the value of surface roughness of heat cured acrylic resin should not exceed $0.2 \mu \mathrm{m}$, which is the value of the surface roughness of dental materials that acceptable for oral cavity clinically, as supported by the research done by Abuzar et al. ${ }^{7}$

The results showed an increase in surface roughness. There were changes of roughness value in the control group, expectedly because of the nature of heat cured acrylic resin which absorbs the liquid. Heat cured acrylic resin has liquid absorption value of $0.69 \mathrm{mg} / \mathrm{cm}^{2}$ Acrylic resin consists of polymethyl methacrylate that having a polar ester group $(\mathrm{COOH})$. Polar compounds have hydrophilic nature, means easily absorbs fluid. This is supported by Ferracane's research which stated that the material that having an ester group had a hydrophilic property. ${ }^{19}$ The absorption of liquid occurs by diffusion. Diffusion is the net movement of a substance through a gap. The water molecules penetrate into the polymethyl methacrylate chain and fill positions between the polymer chains. The presence of water molecules that penetrate the polymer chain causes the polymer to become insulated and separated. The occurrence of this absorption triggers two important effects in the polymerized mass, which causes the polymerized mass undergo an expansion and affects the strength of the polymer chains because it acts as a plasticizer ${ }^{2}$ A separated polymer chain will resulting in the formation of a porus. ${ }^{20}$

Porous is one of the factors that able to increase the surface roughness. According to research conducted by Hiramatsu et al. ${ }^{20}$ stated that the roughest surface of the acrylic resin was the surface of acrylic resin that has the largest number of porous. Porous can also be formed due to the release of residual monomers. The removal of these monomers expectedly cause the formation of porous which can be occupied by water molecules that causes irregular surface. The formation of the irregular surface can causes the increasing value of surface roughness of heat cured acrylic resin.

The increases of surface roughness value before and after immersion in soft drinks solution was higher than the value of surface roughness after immersion in aquadest. The results showed significant difference between the roughness values before and after immersion in soft drinks solution. This can caused by two factors, which were the nature of heat cured acrylic resin that easily absorbs fluid and the low pH degree of soft drinks. As mentioned above, the nature of heat cured acrylic resin can lead to an increase in surface roughness. This absorption process also occured in the treatment group. In this study measured the $\mathrm{pH}$ degree at every changed of the immersion medium (soft drink solution) that was done daily and obtained the average $\mathrm{pH}$ degree of soft drinks which was 3.0. The roughness increase was higher in soft drink solution immersion expectedly caused by acidic content of soft drinks. This was supported by Constantineuscu's research which stated that the roughness of acrylic resin surfaces was increased when immersed in acidic solutions. ${ }^{7}$ The lower the acidity degree of a food or beverages, the higher the value of surface roughness of heat cured acrylic resin. This because the food and beverages that having low degree of acidity contain more hydrogen ions $\left(\mathrm{H}^{+}\right)$ that causes the gap of the polymer chains of heat cured acrylic resin. More amount of the polymer chain gap will increases the monomer gap and will causes the high level of porosity of the acrylic resin. $^{2}$

Acidic content in soft drinks contains more $\mathrm{H}^{+}$ions in its chemical bonds. $\mathrm{H}^{+}$ions will fill gaps between polymer chains in the ester group $(\mathrm{COOH})$ so the $\mathrm{H}^{+}$ions will break the double bonds of $\mathrm{C}(\mathrm{C}=0)$ that owned by polymethyl methacrylate by filling the gaps among the polymer chains so that the polymer chains will be aparted. This will resulting in unstable polymer chain bonding and chemical 
structure bond will be damaged. Esters are easily hydrolyzed with acids and formed numerous cracks on acrylic resin specimen. Number of cracks on the surface of heat cured acrylic resin causes surface irregularity and increases the roughness of the surface of the acrylic resin. ${ }^{2}$ The research done by Rizky et al. stated that acidic content that had a contact with the acrylic resin will disrupted the acrylic bond of polymer chain that lead to the increase of cracks in acrylic resin plate. ${ }^{21}$

\section{CONCLUSION}

Based on the research results can be concluded there was increases in surface roughness of heat cured acrylic resin after immersion in soft drinks solution compared with immersion in aquadest.

\section{REFERENCES}

1. Al-Kheraif AA.The effect of mechanical and chemical polishing techniques on the surface roughness of heat-polymerized and visible light-polymerized acrylic denture base resins. Saudi Dental J 2014;(26):56-62.

2. Anusavice KJ. Phillips' science of dental materials. $11^{\text {th }}$ ed. Philadelphia: WB Saunder; 2003. p. 722-54.

3. David D, Munadziroh E. Acrylic resin plate color changes soaked in disinfecting solution of sodium hypochlorite and chlorhexidine. Dent J 2005;38(1):36-40.

4. Pereira-Cenci T, Delbelcury AA, Crielaard W, Ten cate JM. Development of candidaassociated denture stomatitis. J Appl Oral Sci 2008;16(2):86-91.

5. Wieckiewicz M, Opitz V, Richter G. Physical properties of Polyamide-12 versus PMMA denture base material. Hindawi J 2014 (1):18.

6. Puspitasari D, Saputera D, Anisyah RN. Title. Acrylic Resin type hardness comparison heat cured on alkaline peroxide disinfecting solution soaking with extract with Celery (Apium graveolens L.) 75\%. Odonto Dent J 2016;3(1): 34-41

7. Abuzar M, Bellur S, Duong N, Kim B, Lu P, Palfreyman N. Evaluating surface roughness of a polyamide denture base material in comparison with poly (methyl methacrylate).
J Oral Sci 2010;52(4):577-81.

8. Eliades $G$. Dental materials in vivo aging and related phenomena. Chicago: Quintessence Publishing Co., Inc.; 2003.

9. Constantineuscu IR, Maria U, Mardarez D. Effect of $\mathrm{pH}$ on the surface roughness of heat cured denture base acrylic resins. Rev Med Chir Soc Med Nat Lasi. 2007;111(2):477-81.

10. Badra VV, Faraoni JJ, Ramos RP, Palmap-Dibb RG. Influence of different beverages on the microhardness and surface roughness of resin composites. Oper Dent 2005;30(2):213-9.

11. Bamise CT, Kolawol KA, Oloyede EO. The determinants and control of soft drinksincited dental erosion. Rev Clin Pesq Odontol 2009:5(2):141-5.

12. Tahmassebi JF, Duggal MS, Malik-Kotru G, Curzon MEJ. Soft drinks and dental health: A review of the current literature. J Dentist 2006;34:2-11.

13. Prasetya RC. Comparison of the number of salivary bacterial colonies in caries and non caries children consumes carbonated beverages. Indonesian J Dentistry; 2008; 15(1):65-70.

14. Evandari Dewi. Pengaruh minuman berkarbonasi terhadap kekasaran permukaan resin akrilik heat cured. Skripsi. Makassar: Universitas Hasanuddin. 2014. p. 38-46.

15. Daughter of RD, Diansari V, Sundari I. Effect of Aceh ulee kareng coffee on the roughness of base of denture of acrylic. J dentofacial; 2011:10(3):135.

16. Krishna NKMA, Nirvana I. Soaking in water for eight days resulted in the removal of minimal residual monomers from a denture base type of cold cure. Mater Dent J; 2009;1(2):15.

17. Daulay AY, Ningsih DS, Diansari V. Effect of Soaking Duration of Acrylic Resin Heat Type Cured In Ulee Kareng Coffee Drink (Coffea Robusta) Against Dimensional Changes. Cakradonya Dent J. 2012;4(2):475-542.

18. Consani RLX, Vieira EB, Mesquita MF, et al. Effect of Microwave Disicfection on Physical and Mechanical Properties of Acryl Resin ic. Braz Dent J 2008;19(4):348-53.

19. Ferracane JL. Hygroscopic and hydrolytic effects in dental polymer networks. Dent Mater; 2006;22;211-22.

20. Hiramatsu D, Moretti-Neto R, Ferraz B, Porto V, 
Rubo J. Roughness and porosity of provisional crowns. Rev RPG Post Grad. 2011;18(2):108112.

21. Rizky A, Prasetyo A, Diwya N. Effect of heat cured resin immersion with added woven glass fiber $3 \%$ in robusta coffee solution (Coffea canephora) against transverse power in vitro. Res J; 2013;3(1):1-9. 